\title{
THE INTERRELATIONSHIP BETWEEN THE FACTORS INFLUENCING RETAIL SELECTION BEHAVIOR AND FMCG MARKET NETWORK
}

\section{AZ ÜZLETVÁLASZTÁST BEFOLYÁSOLÓ TÉNYEZÓK ÉS AZ ÉLELMISZERKISKERESKEDELMI ÜZLETHÁLÓZAT KÖLCSÖNHATÁSAI}

\author{
Ibolya Rózsa Pénzes ${ }^{1}$, Éva Pólya ${ }^{2}$ \\ ${ }^{1}$ Social Sciences Department, Wekerle Business School, Hungary \\ ${ }^{2}$ Commerce, Marketing and International Trade Department, Business Administration Faculty, John \\ von Neumann University, Hungary
}

\author{
Keywords: \\ store networks \\ store chains \\ store loyalty \\ factors influencing development \\ store choice \\ Kulcsszavak: \\ üzlethálózat \\ üzletláncok \\ üzlethűség \\ fejlesztést befolyásoló tényezők \\ üzletválasztás
}

\begin{abstract}
From the consumer behaviour perspective the role of retail selection have a salient importance. Hence in the case of FMCG markets network development as a key area of store chains' distribution systems is a substantial tool in competition for customers. In our paper we investigate the main network development influencing factors in the case of main store chains is Hungary. We also detail the relationship between the size and the change of store chains and the consumer store choice, possibilities, and the freedom-level of decision making Összefoglalás

A fogyasztói magatartás szemszögéből vizsgálva a vásárlási döntésekben az üzlethelyválasztás szerepe kiemelt jelentőségü. Éppen ezért az FMCG piacon müködő üzletláncok értékesitési rendszerének kiemelt területét képező hálózatfejlesztés a fogyasztókért folyó verseny fontos eszköze. Jelen munkánkban vizsgáljuk azt, hogy a Magyarországon müködő kiemelt üzletláncok hálózatfejlesztési döntéseit milyen tényezők befolyásolják és az üzlethálózat nagysága, valamint változása milyen összefüggésben van a fogyasztói üzletválasztással, annak lehetőségével és a döntés szabadságfokával.
\end{abstract}

\footnotetext{
1 Pólya Éva

E-mail: polya.eva@gk-uni-neumann.hu
} 


\section{Introduction}

In Fast Moving Consumer Goods market the nature of competition and the behaviour of market actors have changed significantly till the millennium. It can be seen in the change of number and composition of stores, in the intensive usage of commercial marketing tools, in the advancement of service level and in the change of consumer behaviour as well. In the case of companies who operate in Hungary sales system is an accentuated part of store chains' marketing innovations. From the consumer's perspective daily decisions on the place for food purchases can become easily routinish, nevertheless purchase circumstances and their development can have a great influence.

The aim of this investigation is to reveal those factors that influence the most purchase decision making of consumers and also the decisions of store chains on network development. We would also like to highlight the interrelationship between store networks and store choices. Our hypotheses are the followings:

- There is a bidirectional interrelationship between the development of store networks and the store choices of consumers and it represents regional characteristics.

- In store network development decisions for companies the most important factor is the complex purchase power. Settlement store network based on that limits the consumer decisions and the freedom-level of decision making what can be compensated just partially by the consumers.

- Online sales channels can a possible way of store development by providing an access to the services of the company, by improving the store chain's market position and indirectly the freedom level of decision making. There is a significant gap among the differently developed regions of the county and also among different store chains.

- In FMCG retail trade satisfying the increasing need for experience-based shopping differs in the practice of different retail chains, related services and purchase circumstances are also differentiated.

\section{Literature review}

\subsection{Correspondence between store network development and retail selection}

In store chains' activity development and modernization of store network and improvement of sales environment became a salient area of strategic decisions by the intensity growth of market competition. It has a double function: on the one hand it creates a possibility for the customers to purchase and make decision making among different stores, on the other hand it is short-term, but effective tool to improve market position and to influence customers.

Development of retail store chains and their sales environment covers the following fields:

- review of factors that influence store choice behaviour

- changes and size of store retail network,

- the role of store chains and the concentration of stores and returns

\subsection{Factors influencing retail selection}

During the purchase decision making - especially in the phase of decision-making and purchase execution- retail selection is more and more part of the decision making process, because of its importance. [1][2][3][4][5] Store choice requires mental resources, thinking [6]; the decision making process itself does not only include product- and brand choice, but also includes store choice. In time order of purchase decision making store choice precedes product or brand choice [7][8][9][10][11][3][12][13][5] however as to Lantos (2010) the order of these two deed can change.

Nowadays it is typical that the scarcity of time notably influences the behaviour of consumers. If a habitual product or brand is not available in a given store, the customer is tending to buy a substitute product or brand, rather than visiting another store. Hence customers usually make their final decisions on the spot. [14]

Store choice by Lantos (2010) is like brand choice. The only difference is that evaluation is made by different factors. By all of these the customers evaluate first the store type and the 
concurrent and only choose the store afterwards. Before choosing the store chain, customers also have pondered over the available store type possibilities. However the characteristics of the store also have to harmonize with the expectations and features of the consumer and the nature of the purchase. [12] According to Briesch, Chintagunata and Fox (2009) in general price is the most influencing factor, though there can be significant differences in preferences. [15] By Inman, Shankar and Ferraro (2004) different, divergent product categories are purchased in stores what the customers identify firstly with a given category.[16]

Spiggle and Sewall (1987) identified those retailers than can be considered during the purchase decision making process. [17] Their model is an extensive one, impulse and routine purchases can be modelled less. They presume that the customers can choose among several retailers and purchase decision making can be delineated as a set of stores. [18] Retailers can be grouped by the interferences of friends' opinion and references, previous experiences, advertisements, needs and other motivations. It is not always sure that the customer knows all the retailers and he can have different attitudes towards the different familiar retailers as well. As a result of the selection process, only the visited retailers have the possibility to communicate with the customer. Finally the consumer and the retailer come into contact with each other. [18]

According to the model of Assael (2004) demography, lifestyle, economical status and personal characteristics lead to the evolution of purchase needs. [19] Convenience, general price level, the depth of selection and sales personnel occurs as a primary priority. Positive attitude of the consumer depend on how the image of the store and the needs of the given person approach to each other. [20]

After retail selection the customer evaluates in-store stimuli and chooses the wished product for purchase. As long as he is satisfied with both the environment and the products this can lead to loyalty. The model includes all the steps a customer takes during a store choice decision making process. [20]Based on the model of Assael (2004) we introduce henceforward those factors that have a salient and rudimental role in food retail selection. [19]

\subsubsection{Store loyalty}

Tate (1961) was among the firsts who investigated store loyalty, especially in the context of supermarkets. [21] According to Stephenson (1969) store loyalty mostly influenced by the inner attributes of the store like personnel, convenient accessibility, sortiment or prices. [22] By Rhee and Bell (2004) geographical distance are the most determinant factors besides price and sortiment. [23] Zhang et al. (2017) mention store category loyalty, according to them store loyalty exist only on category level. [24]

Store loyalty, satisfaction and basket value are in a close relation the more satisfied the customer is, the more probable that his loyalty at a given store grows, hence basket value also increases. [25]

\subsubsection{Store image}

Store image of a given store includes all those factors that can somehow influence the customer during the retail selection process. Dominant facade has a salient role for retailers as a well-defined, strong character: it can simplify the purchase decision making process and shorten the time spent with searches. 


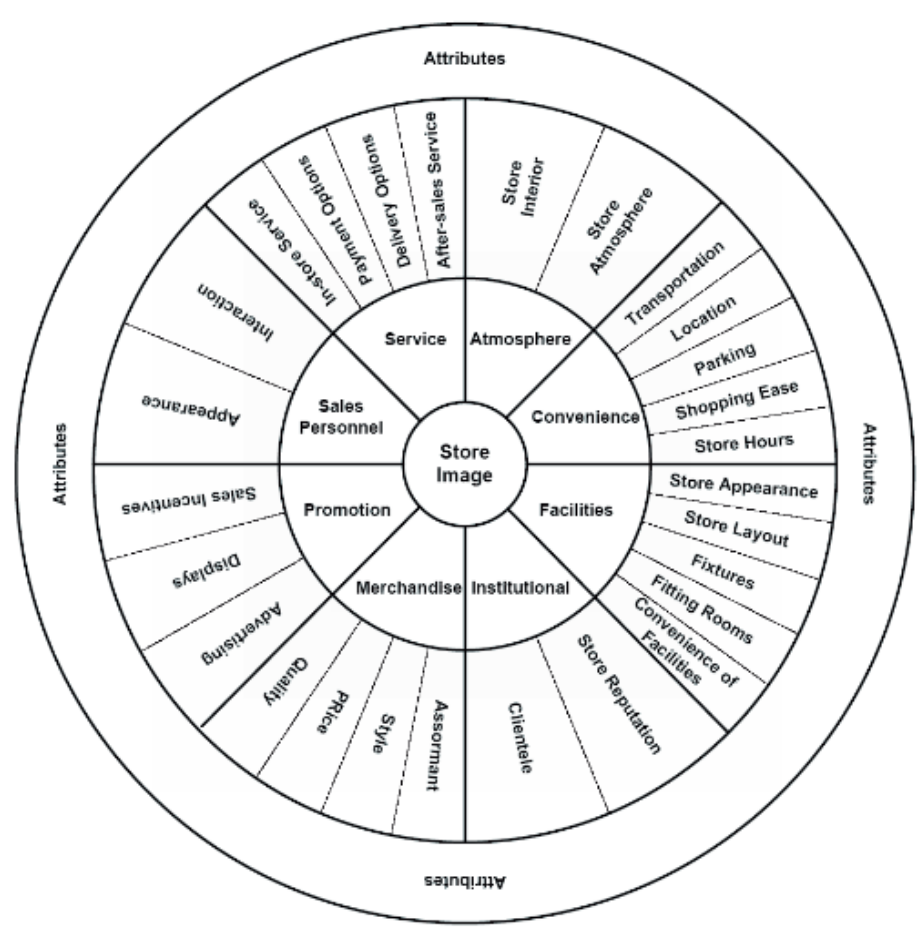

Figure 1 Model of apparel store image [26]

Store image can be influenced by several factors. Among others it includes the scope of goods and provided services, the physical environment, sales personnel, public and available promotions. [27] According to du Preez et al. (2008) consumer variable related to store image have a multiplicity. [26] They identified a wide array of store attributes and subdimensions as it can be seen in Figure 1.

\subsubsection{Sortiment}

In food retail the store sortiment is a determining factor in the prevalence of purchases. Its width and depth can influence the decision and lead to impulse purchases. Not all the retailer have the same brand sortiment, hence retail selection can be influenced by brand preference. By investigating brand compositions it can be seen that consumers have a different opinion about private brands -this type of brand is quite typical in FMCG markets- but most of them acknowledge these brand types. [28]

\subsubsection{Price level, price-quality relations}

Price, and hence price level is determinant in consumer purchase decisions, usually consumers associate to quality by it, therefore the price level of a store grade the store itself and the purchasable products as well.

Consumers are not able to traverse the price of all products therefore he chooses a set of products and reasons the general price level by these. This process can be also influenced by the opinion of peers, by the frequency of rebates and by other available advantages [20]. Advantages usually derive from sales promotion what can have several positive effects on consumers, stores but also on producers. [29] It shows the complexity of consumer decisions that consumers concentrate more and more on price-quality interrelationships instead of mere prices and this fact have a salient role when they make store selection decisions. [28]

\subsubsection{In-store stimuli, store atmosphere}

Parts of the decisions are impulse purchases. These purchases are not planned beforehand in advance; the decision is made on the spot. By Hungarian researches approximately 50-60\% of the purchases are not planned [27] According to Töröcsik (2011) 40$50 \%$ of the purchases are not planned but merely $10-20 \%$ can be considered as impulse purchases. [20] 
Researches on store selection underline that the importance of in-store stimuli is more and more growing by the growing market competition and the growth of store chains' marketing activity. Hence the point of sale must be suitable to display the sortiment, to arouse emotions, and to provide all the necessary information. Besides all of these the sortiment have to be perspicuous and the interior design must emit favourable atmosphere. Store atmosphere can affect the consumers' emotions, the time he spends inside or the fact whether he returns later on. [27] On the other hand designing the atmosphere is not an easy process as it notably depends on the perception of the consumer. As a result style is built up on the combination of different environment psychological elements such as installations, scents, music, colours, lighting. [30]

\section{Summary}

The nature of competition and the behaviour of market actors have changed significantly till the millennium. Not only the composition and number of the stores have changed, but also their commercial marketing tools developed together with the service level. Besides all of these the consumers and their behaviour changed in parallel. However daily food purchases are mainly routine ones, the circumstances of purchase can still have a great influence. In store chains' activity development and modernization of store network and improvement of sales environment became a salient area of strategic decisions by the intensity growth of market competition.

Retail selection is more and more part of the purchase decision making process, because of its importance. The decision making process itself does not only include product- and brand choice, but also includes store choice. As many consumers make convenient purchase decisions, they are tending to buy a substitute product or brand, rather than visiting another store, if a wished brand is not available. Hence customers usually make their final decisions on the spot. It is crucial for the companies to grab the attention of their potential customers and influence them. As it can be seen there are several tools and factors that can help them in that process, we give a priority to introduce several of them in our paper, such as store image, store loyalty, sortiment, price and quality level, in-store stimuli or store atmosphere.

After investigating the domestic FMCG market, we came to the conclusion that the number of stores have decreased. That is the reason of rudimental changes in the owner structure after the system change and the environmental changes as well (such as negative effect of changes in legislation, growth of market competition intensity, changes in owner's strategy and strengthening of consumer consciousness) In the tripolar market the peculiarity of company trade also reflect in store network development together with regional characteristics as a salient part of sales system.

We investigated the store network development activity of store chains operating in Hungary. This is basically determined by complex purchasing power in the case of multinational chains which in the case of Hungarian-owned horizontal cooperative chains is supplemented by the exploitation of competitive advantage and a special approach that treat consumers as a priority. There is a difference in modern, organised store supply between the different counties and settlements we investigated. We can state that consumer freedom level of decision making is high in towns that are located in the upper part of settlement hierarchy, while in villages it is strongly limited.

\section{Acknowledgment}

This research is supported by EFOP-3.6.1-16-2016-00o06 "The development and enhancement of the research potential at John von Neumann University" project. The Project is supported by the Hungarian Government and co-financed by the European Social Fund.

\section{Bibliography}

[1] Hofmeister-Tóth, Á. (2003): Consumer Behavior. Aula Publisher, Budapest

[2] Hofmeister-Tóth, Á. (2008): Basic Consumer Behavior. Aula Publisher, Budapest 
[3] Veres, Z. - Szilágyi, Z. (Ed.) (2006): Basic Marketing. Perfekt Publisher, Budapest

[4] Hawkins, D. I. - Best, R. J. - Coney, K. A. (1986): Consumer Behavior. Homewood: Business Publications Inc. Third Edition

[5] Lantos, G. P. (2010): Consumer Behavior. In: Action Real-Life Applications for Marketing Managers. M.E. Sharpe Inc., New York

[6] Sharma, D. - Madan, P. (2015): Influence of drivers for Store Choice on Store Selection and Loyalty. In: Chatterjee S. e a, Managing in Recovering Markets, Springer India. pp. 343-349.

[7] Monroe, K. B. - Guiltinan, J. P. (1975): A Path-Analytic Exploration of Retail Patronage Influences. In: Journal of Consumer Research

[8] Hofmeister-Tóth, Á. - Törőcsik, M. (1996): Consumer Behavior. National College Textbook Publisher, Budapest

[9] Törőcsik, M. (1998): Retailing marketing. KJK- KERSZÖV Legal and Business Publisher Ltd., Budapest

[10] Bauer, A. - Berács, J. (2002): Marketing. Aula Publisher, Budapest

[11] Lehota, J. - Horváth, Á. - Gyenge, B. (2005): „Qualitative Research of Factors of Consumer Food Store Choice in Retailing”. In: Marketing \& Management 39 (3) pp. 4-16.

[12] Blackwell, R. D. - Miniard, P. W. - Engel, J. F. (2006): Consumer Behavior. G\&S Book Services, 10th Edition

[13] Bauer, A. - Berács, J. - Kenesei, Zs. (2007): Basic Marketing. Series of College Textbook, Aula Publisher, Bologna -Budapest

[14] Törőcsik, M. (2009): Changing of National Consumer Behaviour. In: Consumer Protection Review, pp. 1722.

[15] Briesch, R. A. - Chintagunta, P. K. - Fox, E. J. (2009): How Does Assertment Affect Grocery Store Choice? In: Journal of Marketing Research, 6 (2)

[16] Inman, J. J. - Shankar, V. - Ferraro, R. (2004): The Roles of Channel-Category Associations and Geodemographics in Channel Patronage. In: Journal of Marketing, 88 (2) pp. 51-71.

[17] Spiggle, S. - Sewall, M. (1987): A Choice Sets Model of Retail Selection. In: Journal of Marketing, 51 (April), pp. 100.

[18] Agárdi, I. (2010): Kereskedelmi marketing és menedzsment. Akadémiai, Budapest

[19] Assael, H. (2004): Consumer Behaviour: A Strategic Approach, Houghton Mifflin Company, Boston

[20] Törőcsik, M. (2011): Fogyasztói magatartás. Insight, trendek, vásárlók. Akadémiai, Budapest

[21] Tate, R. S. (1961): The Supermarket Battle for Store Loyalty. In: Journal of Marketing, 25 (6) pp. 8.

[22] Stephenson, P. R. (1969): Identifying determinants of retail patronage. In: Journal of Marketing 33 (49), pp. 57 .

[23] Rhee, H. - Bell, D. R. (2002): The inter-store mobility of supermarket shoppers. In: Journal of Retailing. 78 (4) pp. 225-237.

[24] Zhang, J. - Ptacin, J. L. - Fischer, E. C. - Romesberg, F. E. (2017): A Semi-Synthetic Organism that Stores and Retrieves Increased Genetic Information. In: Nature Science 551 (7682) pp. 644-647.

[25] Piskóti, I. - Nagy, Sz. - Molnár, L. (2010): Üzletválasztási model. Az Unio-Coop esete. In: Piskóti István (Ed..) Marketingkaleidoszkóp, Miskolc, Miskolci Egyetem, Gazdaságtudományi Kar, pp. 235-242.

[26] Preez, Ronel du - Visser, E. -Noordwyk, H. J. van (2008): Store Image. Toward a Conceptual Model Part 1. SA. In: Journal of Industrial Psychology, 34 (2) pp. 50-58.

[27] Hofmeister-Tóth, Á. (2014): A fogyasztói magatartás alapjai. Akadémiai, Budapest

[28] http://trademagazin.hu/hu/hogyan-latja-vasarlo-kiskereskedelmi-uzletlancokat-diszkont-vs-hipermarket/

[29] Marques da Cunha S. - Crespo de Carvalho J. (2006): The Influence of Sales Promotion on Consumers' Store Choice. $5^{\text {th }}$ International Congress Marketing Trends, Venice, pp. 1-23.

[30] Törőcsik, M. (2007): Vásárlói magatartás. Akadémiai, Budapest 